\title{
A Hybrid Power Plant Based on Renewables and Electrochemical Energy Storage and Generation Systems for Decentralized Electricity Supply of the Northern Territories
}

\author{
A.S. Grigoriev ${ }^{1}$, V.V. Skorlygin ${ }^{1}$, S.A. Grigoriev ${ }^{2, *}$, D.A. Melnik ${ }^{1}$, M.N. Filimonov ${ }^{1}$ \\ ${ }^{1}$ National Research Centre "Kurchatov Institute", 1, Kurchatov sq., 123182 Moscow, Russian \\ Federation \\ ${ }^{2}$ National Research University "Moscow Power Engineering Institute”, 14, Krasnokazarmennaya st., \\ 111250 Moscow, Russian Federation \\ *E-mail: sergey.grigoriev@ outlook.com
}

doi: $10.20964 / 2018.02 .54$

Received: 31 October 2017 / Accepted: 1 December 2017 / Published: 28 December 2017

The goal of this paper is to present hybrid power plant based on photovoltaic panels, wind turbine and electrochemical energy storage and generation systems for decentralized power supply of the customers located remotely in northern territories. It was shown that rechargeable electric batteries and low-temperature direct methanol fuel cells could be successfully used in extreme northern conditions instead of diesel generators. Methanol energy storage considerably surpasses accumulator batteries by its capacitance characteristics, being especially important during periods of prolonged absence of energy supply from sun and wind, e.g., under the conditions of polar night and windless weather.

Keywords: hybrid energy system; decentralized power supply; electrochemical energy storage; direct methanol fuel cell; renewable energy sources

\section{FULL TEXT}

(C) 2018 The Authors. Published by ESG (www.electrochemsci.org). This article is an open access article distributed under the terms and conditions of the Creative Commons Attribution license (http://creativecommons.org/licenses/by/4.0/). 